ISSN 1678-3921

Journal homepage: www.embrapa.br/pab

For manuscript submission and journal contents, access: www.scielo.br/pab

\section{Sugarcane harvest time for processing and technological quality of brown sugar}

\begin{abstract}
The objective of this work was to evaluate the optimal harvest time of ten genotypes of sugarcane (Saccharum officinarum) for the processing and quality of brown sugar. The experiment was carried out in a randomized complete block design in a $3 \times 10$ factorial arrangement in split plots, with three harvest times and ten sugarcane genotypes, in the state of São Paulo, Brazil. The qualitative parameters of brown sugar were evaluated by Scott-Knott's test, at 5\% probability. The harvest season in September, known as the middle of the harvest, is the most suitable for the production of brown sugar due to the higher of ${ }^{\circ}$ Brix values of cane, ${ }^{\circ}$ Brix of the broth, pol of brown sugar, and total reducing sugars in this period. The harvesting of the sugarcane genotypes in June-July is the most favorable for the production of brown sugar for the color characteristics $a^{*}, b^{*}, L^{*}$, and chroma; however, it is also the period of production of brown sugar with a lower sugar content. The third harvest season (November) is the least recommended for brown sugar production due to the higher fiber and purity values. The most suitable genotype for brown sugar production and quality is 'IACSP04-704'.
\end{abstract}

Index terms: Saccharum officinarum, ${ }^{\circ}$ Brix, genotype, production, reducing sugars.

\section{Época de colheita da cana-de-açúcar para processamento e qualidade tecnológica de açúcar mascavo}

Resumo - O objetivo deste trabalho foi avaliar a época ideal de colheita de dez genótipos de cana-de-açúcar (Saccharum officinarum) para o processamento e a qualidade de açúcar mascavo. $\mathrm{O}$ experimento foi realizado em delineamento de blocos ao acaso, em arranjo fatorial 3x10, em parcelas subdivididas, com três épocas de colheita e dez genótipos de cana-de-açúcar, no estado de São Paulo, Brasil. Os parâmetros qualitativos de açúcar mascavo foram avaliados pelo teste de Scott-Knott, a 5\% de probabilidade. A época de colheita em setembro, conhecida como meio de safra, é a mais adequada para a produção de açúcar mascavo, em razão dos maiores valores de ${ }^{\circ}$ Brix da cana, ${ }^{\circ}$ Brix do caldo, valor pol do mascavo e açúcares totais redutores nesse período. A colheita dos genótipos de cana-de-açúcar em junho-julho é a mais favorável para a produção de açúcar mascavo quanto às características de coloração a*, b*, L* e croma; no entanto, é também o período de produção de açúcar mascavo com menores teores de açúcar. A terceira época de colheita (novembro) é a menos recomenda para a produção de açúcar mascavo, em razão dos maiores valores de fibra e pureza. O genótipo mais adequado para a produção e a qualidade de açúcar mascavo é o 'IACSP04-704'.

Termos para indexação: Saccharum officinarum, ${ }^{\circ}$ Brix, genótipo, produção, açúcares redutores. 


\section{Introduction}

The cultivation of sugarcane (Saccharum officinarum L.) is of great economic importance for the sugar and energy industry, from which purposes, ethanol production stands out, while for animal use, sugarcane silage is employed. As for human consumption, there is a greater range of products with emphasis on the production of sugar, sugarcane liquor, raw brown sugar (rapadura), cane molasses, and brown sugar (Santos et al., 2020).

Sugarcane is one of the main crops produced around the world, and its grown in more than 100 countries. From its production, $83 \%$ is concentrated in ten countries, including Brazil, considered the largest world producer of this crop, with about $37 \%$ of the production, which represents 746 million tonnes per year (FAO, 2021).

Sugarcane estimated production of Brazil for 2021 is 667,4 thousand tonnes, which represents a small decrease $(1.5 \%)$ in comparison with the previous year that reached 667,9 thousand tonnes (Indicadores IBGE..., 2021). São Paulo is considered as the largest producer state of this crop (54.1\%), reaching an average productivity of $81,656 \mathrm{~kg} \mathrm{ha}^{-1}$ and a total production of approximately 361,5 thousand tonnes (Acompanhamento..., 2020).

The harvest season of different genetic materials and different maturity groups has generally large variations. Consequently, the quality of the final product can be affected due to inadequate maturation at harvest time, or due to unfavorable climatic conditions during cultivation (Adetoro et al., 2020). Therefore, it is important and necessary to determine the harvest season for the best yield and quality of the product that will go to the consumer in the future.

Brown sugar, also known as noncentrifugal sugar (NCS), panela, jaggery, muscovado and kokuto is very popular for its strong aroma, sweetness, and nutritional value, and it is commonly produced and consumed in several countries. Brown sugar is defined as a by-product obtained from the evaporation of sugarcane broth and cooking until the occurrence of crystallization point of sucrose (Jaffé, 2015). This, in the final process, shows a dark color, and preserves its minerals better, since it does not undergo refinement and clarification processes (Durán et al., 2012). For the quality of sugar, some of its main attributes - such as sucrose, total reducing sugars, minerals, and the amount of water - are considered in the final product (Jaffé, 2015).

The knowledge of the relationships between the quality of sugarcane, the amount of sucrose, and the quality of the final product allows of the advance of information on both the quality of brown sugar and on its productive factors (Alarcón et al., 2020) Furthermore, knowing these characteristics for the quality of the final product is also a very important factor, since the qualitative attributes directly reflect the amount paid by the industry to the producer (Silva et al., 2014).

The objective of this work was to evaluate the optimal harvest season of ten genotypes of sugarcane for the processing and quality of brown sugar.

\section{Materials and Methods}

To obtain brown sugar, an experiment was installed in a conventional planting and fertilization system. The experimental area was located in the Research and Development Unit of APTA (Agência Paulista de Tecnologia dos Agronegócios), at $22^{\circ} 17^{\prime} \mathrm{S}, 48^{\circ} 34^{\prime} \mathrm{W}$, and $580 \mathrm{~m}$ altitude, in the municipality of Jaú, in the state of São Paulo, Brazil. The soil in the area is characterized as a Latossolo Vermelho eutrófico (Santos et al., 2013). According to the Köppen-Geiger's classification, the climate is Aw, with the dry season defined in the winter months, and annual averages of $21.6^{\circ} \mathrm{C}$ temperature and about $1,300 \mathrm{~mm}$ precipitation (Alvares et al., 2013).

The work was carried out with a view to the production of brown sugar in three different harvest seasons and from a single planting time (cane of one year and a half). The planting was carried out in the first half of April 2013, with variations only of harvest seasons, which occurred in 2014. The first season (S1) corresponds to the initial harvest period (June-July, with 15 months of cultivation), the second season (S2) corresponds to the mid-harvest period (September, with 17 months of cultivation), and the third season (S3) corresponds to the period considered as the end of the harvest (November, with 19 months of cultivation).

Ten sugarcane genotypes were evaluated, eight from which are commercial cultivars (IACSP 93-3046, IACSP 95-5094, IACSP 97-4039, IACSP 95-5000, RB 86-7515, IACSP 96-3060, RB 96-6928, and SP 81-

Pesq. agropec. bras., Brasília, v.56, e02435, 2021

DOI: 10.1590/S1678-3921.pab2021.v56.02435 
3250), and two are noncommercially released clones (IACSP04-656 and IACSP04-704).

The maturation cycles of each genotype are early (IACSP97-4039), early-medium (RB 96-6928), medium (SP 81-3250, IACSP 95-5000, IACSP 955094), medium-late (IACS 93-3046, RB 86-7515), and late cycle (IACSP 96-3060). For noncommercial clones, there is no information on this characteristic.

A randomized complete block design was carried out with four replicates, in a 3x10 factorial arrangement with split plots, whose genotypes were randomized in the subplots, and the harvest seasons in the main plots. The plots were composed of five grooves of $8 \mathrm{~m}$, spaced at $1.5 \mathrm{~m}$ between rows. The useful area of the plot was $60 \mathrm{~m}^{2}$, and the total area used was $2,400 \mathrm{~m}^{2}$.

Sugarcane was manually harvested at the appropriate point of maturation (above $18{ }^{\circ}$ Brix) of each cultivar, without prior burning, always at the end of the day, on the eve of the processing. The stalks were cropped at two internodes below the heart of the palm breaking point and weighed on a digital scale. The samples were harvested in zigzag, in one third of the plot, in the five existing grooves. Each sample collected contained 62 stalks, 12 of which were sent for the analysis of the technological quality of the raw material, which evaluated the following variables: ${ }^{\circ}$ Brix of the cane; fiber (\%); purity (\%); and pol of cane (\%), that is the sucrose content of the broth, considering the percentage of stalk fiber; and total recoverable sugar $\left(\mathrm{kg} \mathrm{t}^{-1}\right)$. The remaining 50 stalks were used to extract the broth in a small mill from a single suit, without soaking. After that, the samples were weighed for data collection and determination of the ${ }^{\circ}$ Brix of broth, and pol of broth (\%), which refers to the apparent sucrose content contained in the broth.

The processing for the production of brown sugar was carried out on a laboratory scale, in accordance with good food manufacturing practices, using $8 \mathrm{~L}$ of cane broth, in open aluminum pans with 20 L capacity, on a stove with high-pressure gas. Upon reaching a temperature around $50^{\circ} \mathrm{C}, 2.5 \mathrm{~g} \mathrm{~L}^{-1}$ of sodium bicarbonate (food grade) were added as an adjunct in the process, for cleaning and clarifying the cane broth. After reaching the crystallization point, the pan was removed from the heat, to perform the manual batting operation.

The brown sugar samples from each treatment were analyzed for instrumental color using a Minolta model
CR400 portable colorimeter (Konica Minolta, Ramsey, NJ, USA), CIELAB scale (Konica Minolta, 1998). The device measures the following coordinates: L*, which represents the luminosity on a scale from zero (black) to one hundred (white); $a^{*}$, which represents a scale of shades from red $(0+a)$ to green $(0-a) ; b^{*}$, which represents a scale of shades from yellow $(0+b)$ to blue $(0-b)$; and chroma $\left(\mathrm{C}^{*}\right)$, which is responsible for defining the color intensity, with zero in the center, and increasing values according to the distance from the center (Durán et al., 2012). The content of soluble solids of brown sugar was determined in an automatic benchtop refractometer Reichert model I300, and the readings of the apparent sucrose content of brown sugar, called pol of brown sugar (PBS, \%) was measured in polarimeter Anton Paar brand, model MCP200.

The results were subjected to the analysis of variance, in order to verify the effect of harvest times and genotypes and, when significant, the means of the variables were discriminated by the Scott-Knott's test, at $5 \%$ probability. The analyses were performed with the R Core Team software (2020).

\section{Results and Discussion}

A similarity was observed for the qualitative variables that showed interaction between genotypes and seasons. ${ }^{\circ}$ Brix of the cane (BC), total recoverable sugar (TRS), pol of cane (PC), and pol of broth (PB) showed that the second harvest season (September) is the best harvest season for the brown sugar production, followed by seasons 3 and 1, respectively (Table 1). The possible cause for this result may be related to the factors linked to genotypes, as well as to the climatic conditions to which they were subjected. These causes corroborate the results obtained by Adetoro et al. (2020), in a research also carried out with the cultivation of sugarcane.

Among the factors related to the genotypes, the precocious ones in general were more appropriate to be harvested in the first (June-July), or second season (September), while those of the medium cycle were more productive to these variables in September. The later genotypes indicated a greater predisposition to harvest in the late period (November), and they were, in general, unfit and less productive in the first period of the present study. 
In relation to climatic factors, which are important for the yield of sugarcane and sucrose, temperature and rainfall are especially noteworthy (Adetoro et al., 2020). Rainfall is an important factor for the quality of the raw material and, in the case of PC, dry periods or those with less rainfall show greater accumulations of apparent sucrose content (Marin et al., 2019). This statement corroborates the results obtained in the present work, as PC showed an increase above the normal, which can be attributed to the lower rainfall occurred during the year 2014 (Boletim..., 2014). It is interesting to mention that the fact is also valid for other variables that are related to the final accumulation of sugar.

Marin et al. (2019) considered six different environments and found results of $\mathrm{PC}$ ranging from 10 to $15 \%$, which are lower than those found in the present study. The same authors concluded that this small variation occurred due to different harvest numbers.

No significant differences were found between genotypes in the season 2 for the ${ }^{\circ} \mathrm{BC}, \mathrm{PC}$, TRS, and $\mathrm{PB}$ variables (Table 1). Likewise, Albuquerque et al.

Table 1. Technological variables with interaction in genotypes of sugarcane (Saccharum officinarum), in the first (S1), second (S2), and third (S3) harvest seasons, in the municipality of Jaú, in the state São Paulo, Brazil ${ }^{(1)}$.

\begin{tabular}{|c|c|c|c|c|c|c|c|c|}
\hline \multirow[t]{2}{*}{ Genotype } & \multicolumn{4}{|c|}{${ }^{\circ}$ Brix degree of cane $-{ }^{\circ} \mathrm{BC}$} & \multicolumn{4}{|c|}{ Total recoverable sugars - TRS $\left(\mathrm{kg}\right.$ ton $\left.^{-1}\right)$} \\
\hline & S1 & S2 & S3 & GA & S1 & S2 & S3 & GA \\
\hline IACSP04-656 & $20.27 \mathrm{Bc}$ & 24.17Aa & $22.26 \mathrm{Ab}$ & 22.23 & $155.01 \mathrm{Bc}$ & $179.46 \mathrm{Aa}$ & $168.41 \mathrm{Bb}$ & 167.63 \\
\hline IACSP04-704 & $21.34 \mathrm{Ac}$ & $23.88 \mathrm{Aa}$ & $22.49 \mathrm{Ab}$ & 22.57 & $165.85 \mathrm{Ab}$ & $182.96 \mathrm{Aa}$ & $179.90 \mathrm{Aa}$ & 176.24 \\
\hline IACSP93-3046 & $20.08 \mathrm{Bc}$ & $23.02 \mathrm{Aa}$ & $21.42 \mathrm{Bb}$ & 21.51 & $152.74 \mathrm{Bc}$ & $172.82 \mathrm{Aa}$ & $161.18 \mathrm{Cb}$ & 162.25 \\
\hline IACSP95-5000 & $20.37 \mathrm{Bc}$ & 24.14Aa & $22.52 \mathrm{Ab}$ & 22.34 & $155.00 \mathrm{Bc}$ & $182.70 \mathrm{Aa}$ & $170.53 \mathrm{Bb}$ & 169.41 \\
\hline IACSP95-5094 & $20.59 \mathrm{Bc}$ & $23.73 \mathrm{Aa}$ & $22.20 \mathrm{Ab}$ & 22.17 & $155.71 \mathrm{Bc}$ & $176.83 \mathrm{Aa}$ & $164.17 \mathrm{Cb}$ & 165.57 \\
\hline IACSP96-3060 & $19.21 \mathrm{Bc}$ & $24.35 \mathrm{Aa}$ & $23.24 \mathrm{Ab}$ & 22.27 & $149.76 \mathrm{Bb}$ & $181.20 \mathrm{Aa}$ & $176.63 \mathrm{Aa}$ & 169.20 \\
\hline IACSP97-4039 & $21.01 \mathrm{Ab}$ & $24.13 \mathrm{Aa}$ & $21.61 \mathrm{Bb}$ & 22.25 & $162.58 \mathrm{Ab}$ & $178.50 \mathrm{Aa}$ & $161.90 \mathrm{Cb}$ & 167.66 \\
\hline RB86-7515 & $20.00 \mathrm{Bc}$ & $23.78 \mathrm{Aa}$ & $21.59 \mathrm{Bb}$ & 21.81 & $154.36 \mathrm{Bb}$ & $174.51 \mathrm{Aa}$ & $160.76 \mathrm{Cb}$ & 163.21 \\
\hline RB96-6928 & $20.32 \mathrm{Bc}$ & $23.23 \mathrm{Aa}$ & $21.40 \mathrm{Bb}$ & 21.65 & $155.99 \mathrm{Bb}$ & $175.15 \mathrm{Aa}$ & $159.82 \mathrm{Cb}$ & 163.65 \\
\hline SP81-3250 & $21.18 \mathrm{Ab}$ & $23.94 \mathrm{Aa}$ & $21.17 \mathrm{Bb}$ & 22.10 & $161.65 \mathrm{Ab}$ & $175.62 \mathrm{Aa}$ & $153.28 \mathrm{Cb}$ & 163.52 \\
\hline GA & 20.44 & 23.84 & 21.99 & & 156.87 & 177.98 & 165.66 & \\
\hline $\mathrm{CV}_{\mathrm{PP}}(\%)$ & & 3.33 & & & & 4.28 & & \\
\hline \multirow[t]{2}{*}{$\mathrm{CV}_{\mathrm{SP}}(\%)$} & & 3.05 & & & & 3.51 & & \\
\hline & \multicolumn{4}{|c|}{ Pol of cane - PC (\%) } & \multicolumn{4}{|c|}{ Pol of broth - PB (\%) } \\
\hline IACSP04-656 & $15.70 \mathrm{Bc}$ & $18.21 \mathrm{Aa}$ & $17.12 \mathrm{Bb}$ & 17.01 & $18.59 \mathrm{Ab}$ & $21.91 \mathrm{Aa}$ & $20.67 \mathrm{Aa}$ & 20.39 \\
\hline IACSP04-704 & $16.79 \mathrm{Ab}$ & $18.58 \mathrm{Aa}$ & $18.38 \mathrm{Aa}$ & 17.92 & $19.46 \mathrm{Ab}$ & $21.82 \mathrm{Aa}$ & $21.63 \mathrm{Aa}$ & 20.97 \\
\hline IACSP93-3046 & $15.44 \mathrm{Bb}$ & $17.53 \mathrm{Aa}$ & $16.34 \mathrm{Cb}$ & 16.44 & 18.29Ab & $21.00 \mathrm{Aa}$ & $19.65 \mathrm{Ba}$ & 19.65 \\
\hline IACSP95-5000 & $15.69 \mathrm{Bc}$ & $18.57 \mathrm{Aa}$ & $17.33 \mathrm{Bb}$ & 17.20 & $18.54 \mathrm{Ab}$ & $22.10 \mathrm{Aa}$ & $20.83 \mathrm{Aa}$ & 20.49 \\
\hline IACSP95-5094 & $15.78 \mathrm{Bb}$ & 17.98Aa & $16.67 \mathrm{Cb}$ & 16.81 & $18.98 \mathrm{Ab}$ & $21.83 \mathrm{Aa}$ & $22.93 \mathrm{Aa}$ & 21.25 \\
\hline IACSP96-3060 & $15.14 \mathrm{Bb}$ & 18.39Aa & 17.98Aa & 17.17 & $17.64 \mathrm{Ab}$ & $22.03 \mathrm{Aa}$ & $21.61 \mathrm{Aa}$ & 20.43 \\
\hline IACSP97-4039 & $16.49 \mathrm{Ab}$ & $18.07 \mathrm{Aa}$ & $16.38 \mathrm{Cb}$ & 16.98 & $19.37 \mathrm{Ab}$ & $21.53 \mathrm{Aa}$ & $19.57 \mathrm{Bb}$ & 20.16 \\
\hline RB86-7515 & $15.64 \mathrm{Bb}$ & $17.66 \mathrm{Aa}$ & $16.29 \mathrm{Cb}$ & 16.53 & $18.49 \mathrm{Ab}$ & $21.28 \mathrm{Aa}$ & $19.72 \mathrm{Bb}$ & 19.83 \\
\hline RB96-6928 & $15.78 \mathrm{Bb}$ & $17.77 \mathrm{Aa}$ & $16.14 \mathrm{Cb}$ & 16.56 & $18.57 \mathrm{Ab}$ & $21.17 \mathrm{Aa}$ & $19.22 \mathrm{Bb}$ & 19.65 \\
\hline SP81-3250 & $16.36 \mathrm{Ab}$ & $17.78 \mathrm{Aa}$ & $15.42 \mathrm{Cc}$ & 16.52 & $19.32 \mathrm{Ab}$ & $21.40 \mathrm{Aa}$ & $18.61 \mathrm{Bb}$ & 19.78 \\
\hline GA & 15.88 & 18.05 & 16.81 & & 18.73 & 21.61 & 20.44 & \\
\hline $\mathrm{CV}_{\mathrm{PP}}(\%)$ & & 4.65 & & & & 6.48 & & \\
\hline $\mathrm{CV}_{\mathrm{SP}}(\%)$ & & 3.77 & & & & 5.85 & & \\
\hline
\end{tabular}

(1)Means followed by equal letters, uppercases in the columns and lowercases in the lines, do not differ from each other by the Scott-Knott's test, at $5 \%$ probability. GA, general averages. $\mathrm{CV}_{\mathrm{PP}}(\%)$, coefficient of variation in relation to the genotype. $\mathrm{CV}_{\mathrm{SP}}(\%)$, coefficient of variation in relation to the season. 
(2016) also found no significant differences for the determination of ${ }^{\circ} \mathrm{BC}$ with sugarcane genotypes tested in a similar harvest season to that of September, also called the middle harvest season. Moreover, the same fact occurred with the studies by Weerawatanakorn et al. (2016) and Misra et al. (2020), who found mean values of $18.46^{\circ}$ and $19.53{ }^{\circ}$ Brix, respectively.

For the season 1, considered the least suitable for the harvest and evaluation of the ${ }^{\circ} \mathrm{BC}$ and TRS variables (Table 1), the best genotypes were those of early or medium cycle, which in this period would have reached or would be close to the final maturation. The genotypes 'IACSP04-704' (not released commercially), 'SP81-3250' (early-medium cycle), and 'IACSP97-4039' (early cycle) showed 21.34, 21.18, and $21.01{ }^{\circ}$ Brix for ${ }^{\circ} \mathrm{BC}$ values, and $165.85,161.65$, and $162.58 \mathrm{~kg}^{-1}$ ton ${ }^{-1}$ for TRS, respectively. Late cycle genotypes that would be developing and, therefore, not yet accumulating final sugars, had the lowest values for these variables, like the 'IACSP96-3060' (long cycle), that showed 19.21 ${ }^{\circ}$ Brix for ${ }^{\circ} \mathrm{BC}$, and $149.76 \mathrm{~kg}^{-1}$ ton $^{-1}$ for TRS.

The obtained TRS values can be related to characteristics of each genotype, since each one has a flowering characteristic that tends to cause yield decreases of the total recoverable sugars because of the assimilate translocation to the flag leaf for the inflorescence protection. In addition, the postflowering period would result in the formation of new shoots and, therefore, it would negatively affect the amount of TRS (Acompanhamento..., 2018).

The higher the content of sucrose (pol), the greater the industrial yield. Conversely, the more immature it is, the lower will be the pol and the final quality of the product. The season 2 was the best one to obtain higher levels of PC, PB, and pol of brown sugar (PBS) with 18.05, 21.61, and 93.64\%, respectively (Table 1 , and Figure 1).

The PB results of the present work corroborate the findings by Misra et al. (2020) of $21.12 \%$ PB for sugarcane evaluated immediately after harvest. Our work also confirms the results observed by Naseri et al. (2020), who found $17.19 \%$ PB and also observed values for ${ }^{\circ} \mathrm{BB}$ which are similar, but smaller than that seen in our study, with small variations between 18.38 to $19.95 \%$.

The third harvest season was the least favorable one for PB of genotypes 'RB96-6928', 'SP81-3250', 'IACSP97-4039', and 'IACSP93-3046' (Table 1).
'RB86-7515', despite being of mid-late cycle, showed this result due to its greater suitability for fiber production and, therefore, less sucrose accumulation. The genotypes 'SP81-3250' and 'IACSP97-4039' would be the least indicated ones because the timing of their harvest is inadequate, they show a lower amount of sugars, as they are probably still immature and, as a consequence, they would show a lower industrial yield.

In 2014, there was a strong dry season (13.3\% below of the climatological average), that occurred mainly in the months of January, February, June, July, September, and October (Boletim..., 2014). Two of these months reflect the harvest period of the first and second seasons studied in the present work, which, consequently, directly interfered with the results related to the technological quality of the final products obtained (Mendoça et al., 2020).

PBS is an indicator of product quality and has a standard value determined by Brazilian law, which is $90 \%$ for brown sugar commercialization. However, in many cases, this is not achieved by the producers due to the difficulty to reach the adequate point of sugar, and to achieve higher levels of sucrose in the final product (Andrade et al., 2018). The values obtained in the present study for the PBS standard value were acceptable, since they ranged from 91.85 to $95.28 \%$ in the second season (Figure 1). Likewise, for the remaining two other seasons (1 and 3), that are considered less appropriate, the values obtained for genotypes were also higher and, therefore, subject to quality and able to be marketed.

In general, the most prominent genotype for brown sugar production was 'IACSP04-704', which can be attributed to its high averages obtained for the sucrose content variables ${ }^{\circ} \mathrm{BC}, \mathrm{TRS}, \mathrm{PC}, \mathrm{PB}$, and PBS, which were statistically equal or superior to the other genotypes (Table 1 and Figure 1).

In general, the best time observed for the coloring variables related to brown sugar quality: $a^{*}, b^{*}, L^{*}$, and $\mathrm{C}^{*}$ was the first harvest season, which is June-July, while the lowest values were found in the third season, which is November (Table 2 and Figure 1).

It is important to mention that the genotypes have a great influence on the final color of brown sugar and, although there is still no law that regulates their color values, this is one of the parameters used for acceptance or rejection of the marketed product (VeraGutiérrez et al., 2019). This characteristic also causes 
a change in the final color variables of brown sugar $\left(a^{*}, b^{*}\right.$ and $\left.L^{*}\right)$ that are precisely sampled according to the color they portray. The darker or lighter color of $\mathrm{C}^{*}$, for instance, can be derived from, in addition to the characteristics of the genotype, the cooking time, and the high temperatures involved in the production
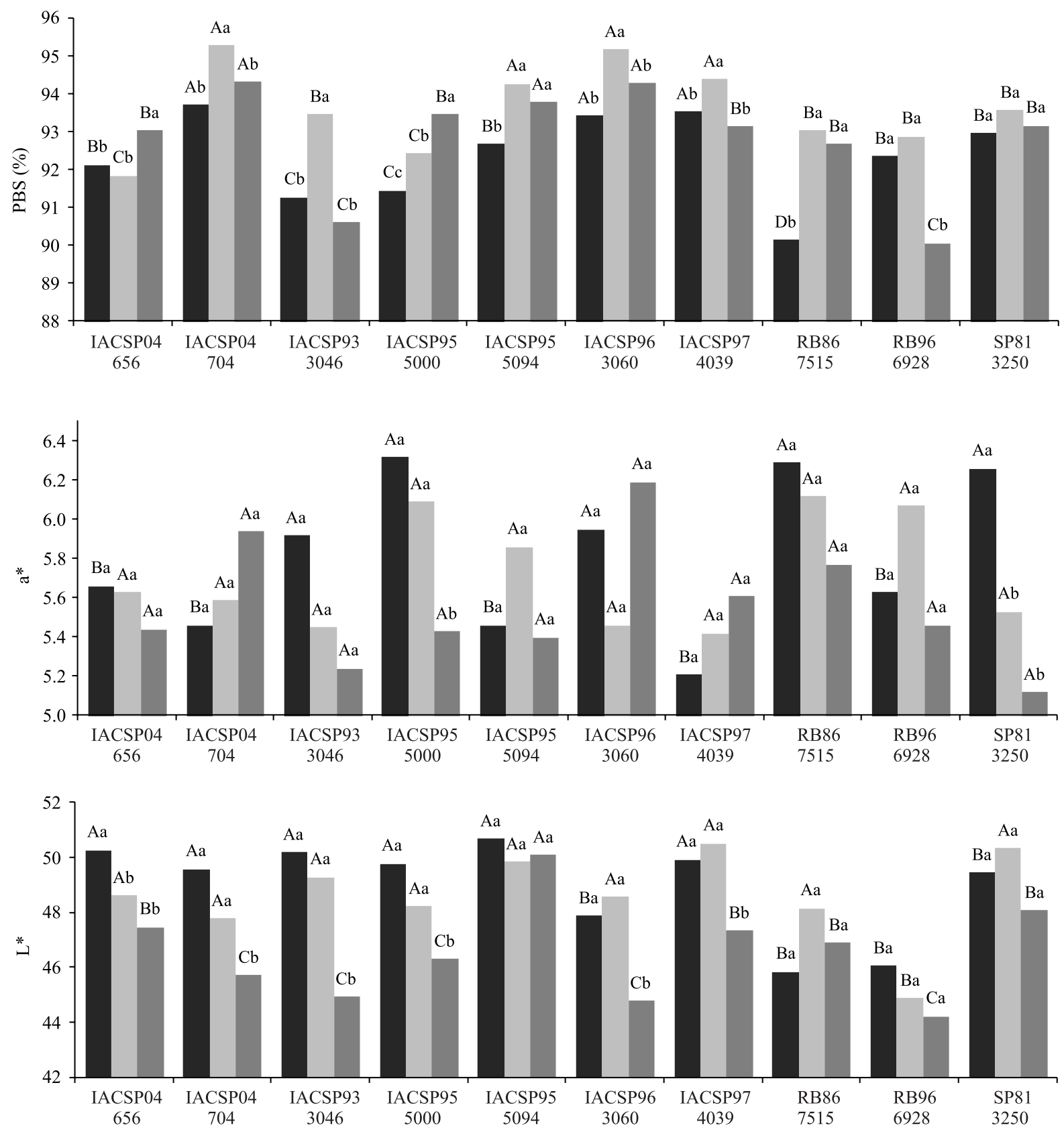

Genotype
$\square \mathrm{S} 1 \square \mathrm{S} 2 \square \mathrm{S} 3$

Figure 1. Technological variables with interaction in genotypes of sugarcane (Saccharum officinarum, in the first (S1), second (S2), and third (S3) harvest seasons, in the municipality of Jaú, in the state of São Paulo, Brazil: PBS, pol of brown sugar; $\mathrm{a}^{*} ; \mathrm{L}^{*} . \mathrm{CV}_{\mathrm{PP}}(\%)$, coefficient of variation in relation to the genotype. $\mathrm{CV}_{\mathrm{SP}}(\%)$, coefficient of variation in relation to the season. $\mathrm{CV}_{\mathrm{PP}}(\%)$ of $\mathrm{PBS}=0.84 ; \mathrm{CV}_{\mathrm{PP}}(\%)$ of $\mathrm{a}^{*}=9.02 ; \mathrm{CV}_{\mathrm{PP}}(\%)$ of $\mathrm{L}^{*}=3.43 ; \mathrm{CV}_{\mathrm{SP}}(\%)$ of $\mathrm{PBS}=0.22 ; \mathrm{CV}_{\mathrm{SP}}(\%)$ of $\mathrm{a}^{*}=$ $8.07 ; \mathrm{CV}_{\mathrm{SP}}(\%)$ of $\mathrm{L}^{*}=3.15$. Means followed by equal letters, uppercases for genotypes and lowercases for harvest seasons, do not differ by the Scott-Knott's test, at 5\% probability. 
of brown sugar. However, there is still no law that regulates brown sugar color values, which is one of the parameters used for the acceptance or rejection, of the marketed product, as already portrayed by Durán et al. (2012) and Vera-Gutiérrez et al. (2019).

According to Silva et al. (2018), values less than 10 for the color variable $\mathrm{a}^{*}$ would be adequate and indicate the presence of a browner color, that is considered normal when the purpose is the production of brown sugar. This value is, therefore, in agreement with the value found in the present study, in which a more reddish coloration was found than in the other studied periods and there was no greenish colorations because the values were all greater than zero (Figure 1).

The color parameter $\mathrm{a}^{*}$ showed all values above 5.12 and less than 6.32. This range is higher than that found in other studies such as García et al. (2017), who obtained values between -1.5 to 3.0 considering different geographic regions. However, according to Lee et al. (2018), negative values can occur in both cases, although they are more common when the final product is refined sugar and has a more whitish color.
Considering the staining variable $\mathrm{L}^{*}$, in the first season, 'IACSP95-5094' stood out for having a slightly lighter color (50.68), besides showing an average higher than these considering the three seasons together (Figure 1). Silva et al. (2018) found for the variable $L^{*}$ higher values of luminosity, which points also to an even lighter color in their tests.

The values found for $\mathrm{L}^{*}$ are much higher than those found by Vera-Gutiérrez et al. (2019), who obtained values ranging from 27.89 to 38.57 for this parameter, in tests with different genotypes and techniques of sugar preparation, which indicates a darker color. García et al. (2017) found in their study values from 71.6 to 89.8 , which are much higher, indicating a lighter color. Such variations can occur because of the final by-products required in each of the surveys.

In the present study, $\mathrm{C}^{*}$ values ranged from 18.00 to 21.04 in the different genotypes (Table 2). These values are higher than the found ones ( 6.0 to 15.8 ) by Vera-Gutiérrez et al. (2019); and they are lower than those observed (22.3 to 42.4) by García et al. (2017).

Table 2. Technological variables without significant interaction in genotypes of sugarcane (Saccharum officinarum) in the first (S1), second (S2), and third (S3) harvest seasons in the municipality of Jaú, in the state of São Paulo, Brazil ${ }^{(1)}$.

\begin{tabular}{|c|c|c|c|c|c|}
\hline Genotypes & ${ }^{\circ} \mathrm{BB}$ & Purity (\%) & Fiber $(\%)$ & $b^{*}$ & $\mathrm{C}^{*}$ \\
\hline IACSP04-656 & $21.35 \mathrm{~A}$ & $89.49^{\text {ns }}$ & $12.82 \mathrm{~B}$ & $20.19 \mathrm{~A}$ & $20.96 \mathrm{~A}$ \\
\hline IACSP04-704 & $22.36 \mathrm{~A}$ & $90.63^{\mathrm{ns}}$ & $11.53 \mathrm{D}$ & $20.24 \mathrm{~A}$ & $21.04 \mathrm{~A}$ \\
\hline IACSP93-3046 & $20.89 \mathrm{~B}$ & $90.75^{\mathrm{ns}}$ & $12.69 \mathrm{~B}$ & $19.42 \mathrm{~A}$ & $20.21 \mathrm{~A}$ \\
\hline IACSP95-5000 & $22.06 \mathrm{~A}$ & $90.99^{\mathrm{ns}}$ & $12.51 \mathrm{C}$ & $18.99 \mathrm{~A}$ & $19.90 \mathrm{~A}$ \\
\hline IACSP95-5094 & $21.87 \mathrm{~A}$ & $91.35^{\mathrm{ns}}$ & $13.57 \mathrm{~A}$ & $19.86 \mathrm{~A}$ & $20.64 \mathrm{~A}$ \\
\hline IACSP96-3060 & $21.49 \mathrm{~A}$ & $91.69^{\mathrm{ns}}$ & $12.34 \mathrm{C}$ & $18.63 \mathrm{~B}$ & $19.54 \mathrm{~A}$ \\
\hline IACSP97-4039 & $21.81 \mathrm{~A}$ & $91.73^{\mathrm{ns}}$ & $12.28 \mathrm{C}$ & $19.25 \mathrm{~A}$ & $21.01 \mathrm{~A}$ \\
\hline RB86-7515 & $21.55 \mathrm{~A}$ & $91.75^{\mathrm{ns}}$ & $12.89 \mathrm{~B}$ & $18.53 \mathrm{~B}$ & $19.50 \mathrm{~A}$ \\
\hline RB96-6928 & $20.60 \mathrm{~B}$ & $91.85^{\mathrm{ns}}$ & $12.26 \mathrm{C}$ & $17.06 \mathrm{C}$ & $18.00 \mathrm{~B}$ \\
\hline SP81-3250 & $21.66 \mathrm{~A}$ & $92.04^{\mathrm{ns}}$ & $12.77 \mathrm{~B}$ & $19.37 \mathrm{~A}$ & $20.17 \mathrm{~A}$ \\
\hline $\mathrm{CV}_{\mathrm{PP}}(\%)$ & 3.47 & 2.21 & 4.24 & 7.58 & 7.03 \\
\hline S1 & $21.26 \mathrm{~b}$ & $91.58 \mathrm{a}$ & $11.90 \mathrm{c}$ & $20.26 \mathrm{a}$ & $21.08 \mathrm{a}$ \\
\hline S2 & $22.63 \mathrm{a}$ & $90.63 b$ & $12.77 \mathrm{~b}$ & $19.43 b$ & $20.28 b$ \\
\hline S3 & $20.80 \mathrm{c}$ & $91.48 \mathrm{a}$ & $13.03 \mathrm{a}$ & $17.77 \mathrm{c}$ & $18.63 \mathrm{c}$ \\
\hline General averages & 21.56 & 91.23 & 12.57 & 19.15 & 20.00 \\
\hline $\mathrm{CV}_{\mathrm{SP}}(\%)$ & 3.57 & 1.98 & 3.43 & 7.39 & 6.92 \\
\hline
\end{tabular}


For the variable $b^{*}$, the highest values showed a more pronounced yellow color, with the absence of a bluish color, which can occur if the values are less than zero. For the $L^{*}$, which is an important variable that influences the acceptance or not of a certain product based on its coloration (Silva et al., 2018), the values found were close to 50 and show that the color was between a dark tone and a lighter tone (Table 2). García et al. (2017) found large variations of the " $b$ *" color values that were between 22.3 to 42.3 , depending on the brown sugar concentration, which were above those seen in the present study, and indicate a more yellow color. However, the author points out that the variation of the coloring characteristic in the final product found in different coloring parameters may occur due to a characteristic of consumer preference in a given region, citing the addition of bleaching agents, for instance, or even due to the final product required, such as juice, sugar, or brown sugar.

The analyzed genotypes that stood out in the first period of the staining variable $\mathrm{a}^{*}$ were the 'IACSP95-5000', 'RB86-7515', 'SP81-3250', 'IACSP96-3060', 'IACSP93-3046', which obtained between 5.92 and 6.32 (Figure 1). These genotypes are of medium or late cycle, and the color found is a more intense red color than in the other genotypes. Silva et al. (2018) found values close to the parameter for $b^{*}$ (24.70), which is higher than that of the present study (21.18).

The worst genotype for the variables $\mathrm{b}^{*}, \mathrm{C}^{*}$ and $\mathrm{L}^{*}$ was the 'RB96-6928' that showed 16\% lower values of $\mathrm{b}^{*}$ comparison to the best result obtained in the tests. For $\mathrm{C}^{*}$, the lowest value found in this genotype was 18.00, while the others showed higher values and did not differ statistically for the variable (Table 2). The parameter $\mathrm{L}^{*}$ also showed the least suitable result in this genotype (45.07), which indicates a darker color (Figure 1). As an exception, for the variable $\mathrm{a}^{*}$, the worst genotype was 'IACSP97-4039', with 5.41 as the genotype average.

As in the variables that consider the total reducing sugar content, such as TRS, ${ }^{\circ} \mathrm{BC}$, and $\mathrm{PB}$, the ${ }^{\circ} \mathrm{BB}$ variable also showed better results in the second harvest season, regardless of the genotype, reaching $22.63{ }^{\circ}$ Brix (Table 2). For ${ }^{\circ} \mathrm{BB}$, the results found for the best genotypes ranged from 21.35 to $22.36{ }^{\circ} \mathrm{Brix}$ (Table 2), which are similar to those found by Silva et al. (2014) in their study in an irrigated condition.
Alarcón et al. (2020) studied the properties of juice and syrup from sugarcane and found ${ }^{\circ} \mathrm{BB}$ higher than $30^{\circ}$ Brix, in comparison to the values observed in the present study, which is due not only to the conditions of the genotype and management, but also to temperature and cooking time. However, Weerawatanakorn et al. (2016) found ${ }^{\circ} \mathrm{BB}$ values ranging from 17.31 to $18.10^{\circ}$ Brix, which are similar to those of the present work.

The third harvest season (November) showed results with the lowest ${ }^{\circ} \mathrm{BB}$ values. This is the period of cane when most genotypes should have been completed their maturation, which is due either to their cycle, or to the translocation of their energy reserve for another purpose, such as fiber production, for instance (Cruz et al., 2014).

Therefore, the more immature the cane, the lower its purity and its quality. In the present work, it can be inferred that the high values obtained from purity reflect in a smaller amount of dirt and, consequently, in a better quality of the final product. Moreover, purity may also be related to the high concentration of sucrose in the broth of the studied cultivars (Tables 1 and 2).

The responses observed in the present study are higher than the reported ones by Silva et al. (2014), who found $88.8 \%$ purity in plant cane in São Paulo, an amount equal to that mentioned by Misra et al. (2020). In the evaluation of purity at different stages of sugar preparation in Colombia, Vera-Gutiérrez et al. (2019) found values higher than $92 \%$, which are very similar to those observed in the present study.

Comparing the seasons of higher values of purity found, with the other studied variables, an inversely proportional relationship with the variable $\mathrm{PC}$ was identified, in which the higher was the PC, the lower was the purity, and the opposite was also valid. The same inverse relationship occurred also for the variables ${ }^{\circ} \mathrm{BC}$ and PC (Tables 1 and 2). Misra et al. (2020) reported a similar fact in a study on sugarcane grown in normal conditions and in drought conditions.

As there is an inversion between fiber values and sugar values, the season known as the end of the cycle (third season) showed a production with the highest fiber content and, therefore, the lowest total reducing sugar content (Table 2). According to Wang et al. (2017), the photosynthetic activity gradually decreases with the maturation of the stalks, thus causing an inversion between fiber and sugar levels. 
According to Silva et al. (2014) and White Jr. et al. (2020), fiber and biomass values tend to be higher in irrigated conditions or periods of high rainfall. The fiber values observed in the present work (Table 2) ranged from 11.53 to 13.57 , and they corroborate the findings by Feder (2021), considering two years of sugarcane cultivation, in which this author found values between 10.20 to 11.02 .

The drier months of 2014 coincided with the sugarcane harvest (June-July and September) that are the least favorable periods for fiber production, while the opposite period of normal weather or higher rainfall is more favorable to this parameter, a fact which occurred in the third period of the present study and that corroborates the results by Mendoça et al. (2020).

Furthermore, the greater accumulation of fiber may also have been favored by the fact that the maturation cycle of these genotypes is of early-medium cycle, which allows them to reach maturation more quickly and, therefore, to enter the process of gradual dehydration, causing the relocation of photoassimilates (Cruz et al., 2014). In this context, a contrary relationship can be verified if we consider the first-second season for this variable, as in these seasons the tendency is a greater accumulation of sugars.

\section{Conclusions}

1. The harvest of the sugarcane (Saccharum officinarum) genotypes in September is the most favorable for the production of brown sugar, for the processing and technological quality of sugar and brown sugar, whereas for the characteristics related to the final coloration of the brown sugar, the most suitable harvest time is June-July.

2. The performance of the harvest in November is the least one recommended aiming at technological quality because of higher concentration of purity and fiber, and lower concentration of total reducing sugars.

3. 'IACSP04-704', the noncommercially released genotype, is the best cultivar for sugar production, as well as for the production and quality of brown sugar.

\section{Acknowledgments}

To Conselho Nacional de Desenvolvimento Científico e Tecnológico (CNPq, 304350/2017-6) and to Coordenação de Aperfeiçoamento Pessoal de Nível
Superior (Capes, Finance Code 001), for granting the scholarships to the researchers; to Agência Paulista de Tecnologia dos Agronegócios (APTA), for the permission to use both its experimental area and the laboratory for analyses.

\section{References}

ACOMPANHAMENTO DA SAFRA BRASILEIRA [DE] CANA-DE-AÇÚCAR: safra 2018/19: primeiro levantamento, v.5, n.1, maio 2018.

ACOMPANHAMENTO DA SAFRA BRASILEIRA [DE] CANA-DE-AÇÚCAR: safra 2020/21: terceiro levantamento, v.7, n.3, dez. 2020.

ADETORO, A.A.; ABRAHAM, S.; PARASKEVOPOULOS, A.L.; OWUSU-SEKYERE, E.; JORDAAN, H.; ORIMOLOYE, I.R. Alleviating water shortages by decreasing water footprint in sugarcane production: the impacts of different soil mulching and irrigation systems in South Africa. Groundwater for Sustainable Development, v.11, art. 100464, 2020. DOI: https://doi.org/10.1016/j.gsd.2020.100464.

ALARCÓN, Á.L.; ORJUELA, A.; NARVÁEZ, P.C.; CAMACHO, E.C. Thermal and rheological properties of juices and syrups during non-centrifugal sugar cane (jaggery) production. Food and Bioproducts Processing, v.121, p.76-90, 2020. DOI: https://doi.org/10.1016/j.fbp.2020.01.016.

ALBUQUERQUE, A.P. da C.; BASTOS, G.Q.; DUTRA FILHO, J. de A.; SOUTO, L.S.; MEDEIROS, A.C. de; SIMÕES NETO, D.E. Seleção de cultivares de cana-de-açúcar para a Zona da Mata Norte de Pernambuco: II: Meio de safra. Revista Verde de Agroecologia e Desenvolvimento Sustentável, v.11, p.62-66, 2016. DOI: https://doi.org/10.18378/rvads.v11i1.4263.

ALVARES, C.A.; STAPE, J.L.; SENTELHAS, P.C.; MORAES GONÇALVES, J.L. de; SPAROVEK, G. Köppen's climate classification map for Brazil. Meteorologische Zeitschrift, v.22, p.711-728, 2013. DOI: https://doi.org/10.1127/09412948/2013/0507.

ANDRADE, L. de A.; MEDEIROS, S.D.S. de; BORGES, M.T.M.R. Avaliação das características físico-químicas do açúcar mascavo adicionado de açúcar bruto de alta polarização.

Brazilian Journal of Food Technology, v.21, e2017199, 2018. DOI: https://doi.org/10.1590/1981-6723.19917.

BOLETIM CLIMATOLÓGICO ANUAL DA ESTAÇÃO METEOROLÓGICA DO IAG/USP. São Paulo: IAG/USP, v.17, 2014. 76p.

CRUZ, L.R. da; GERASEEV, L.C.; CARMO, T.D. do; SANTOS, L.D.T.; BARBOSA, E.A.; COSTA, G.A.; JUNIOR, A. dos S. Características agronômicas e composição bromatológica de variedades de cana-de-açúcar. Bioscience Journal, v.30, p.17791786, 2014.

DURÁN, E.; PÉREZ, R.; CARDOSO, W.; PÉREZ, O.A. Análise colorimétrica de açúcar mascavo e sua aceitação no mercado de Viçosa-MG, Brasil. Revista Temas Agrários, v.17, p.30-42, 2012. DOI: https://doi.org/10.21897/rta.v17i2.700. 
FAO. Food and Agriculture Organization of the United Nations. Faostat. Available at: <http://www.fao.org/faostat/en/\#data $>$. Accessed on: Apr. 2021.

FEDER, F. Irrigation with treated wastewater in humid regions: effects on Nitisols, sugarcane yield and quality. Agricultural Water Management, v.247, art.106733, 2021. DOI: https://doi.org/10.1016/j.agwat.2020.106733.

GARCÍA, J.M.; NARVÁEZ, P.C.; HEREDIA, F.J.; ORJUELA, A.; OSORIO, C. Physicochemical and sensory (aroma and colour) characterisation of a non-centrifugal cane sugar ("panela") beverage. Food Chemistry, v.228, p.7-13, 2017. DOI: https://doi.org/10.1016/j.foodchem.2017.01.134.

INDICADORES IBGE: levantamento sistemático da produção agrícola: estatística da produção agrícola. Rio de Janeiro: IBGE, fev. 2021. 95p.

JAFFÉ, W.R. Nutritional and functional components of non centrifugal cane sugar: a compilation of the data from the analytical literature. Journal of Food Composition and Analysis, v.43, p.194-202, 2015. DOI: https://doi.org/10.1016/j.jfca.2015.06.007.

KONICA MINOLTA. Comunicação precisa da cor: controle de qualidade da percepção a instrumentação. [S.1.], 1998. p.1-59.

LEE, J.S.; RAMALINGAM, S.; JO, I.G.; KWON, Y.S.; BAHUGUNA, A.; OH, Y.S.; KWON, O.-J.; KIM, M. Comparative study of the physicochemical, nutritional, and antioxidant properties of some commercial refined and non-centrifugal sugars. Food Research International, v.109, p.614-625, 2018. DOI: https://doi.org/10.1016/j.foodres.2018.04.047.

MARIN, F.R.; EDREIRA, J.I.R.; ANDRADE, J.; GRASSINI, P. On-farm sugarcane yield and yield components as influenced by number of harvests. Field Crops Research, v.240, p.134-142, 2019. DOI: https://doi.org/10.1016/j.fcr.2019.06.011.

MENDOÇA, M.F. de; DANTAS NETO, J.; SILVA, P.F. da; OLIVEIRA, E.C.A. de. Yield and technological quality of sugarcane under irrigation depths and nitrogen fertilization. Revista Brasileira de Engenharia Agrícola e Ambiental, v.24, p.482-489, 2020. DOI: https://doi.org/10.1590/1807-1929/ agriambi.v24n7p482-489.

MISRA, V.; SOLOMON, S.; HASHEM, A.; ABD_ALLAH, E.F.; AL-ARJANI, A.F.; MALL, A.K.; PRAJAPĀTI, C.P.; ANSARI, M.I. Minimization of post-harvest sucrose losses in drought affected sugarcane using chemical formulation. Saudi Journal of Biological Sciences, v.27, p.309-317, 2020. DOI: https://doi.org/10.1016/j.sjbs.2019.09.028.

NASERI, H.; PARASHKOOHI, M.G.; RANJBAR, I.; ZAMANI, D.M. Sustainability of quantitative and qualitative indicators of sugarcane production under different tillage systems (case study: Khuzestan province of Iran). Environmental and Sustainability Indicators, v.8, art.100046, 2020. DOI: https://doi.org/10.1016/j. indic. 2020.100046 .
R CORE TEAM. R: a language and environment for statistical computing. Vienna: R Foundation for Statistical Computing. 2020. Available at: <https://www.r-project.org/>. Accessed on: Apr. 22021.

SANTOS, F.; EICHLER, P.; MACHADO, G.; DE MATTIA, J.; SOUZA, G. de. By-products of the sugarcane industry. In: SANTOS, F.; RABELO, S.C.; MATOS, M. de; EICHLER, P. (Ed.). Sugarcane biorefinery, technology and perspectives. London: Elsevier, 2020. p.21-48. DOI: https://doi.org/10.1016/ b978-0-12-814236-3.00002-0.

SANTOS, H.G. dos; JACOMINE, P.K.T.; ANJOS, L.H.C. dos; OLIVEIRA, V.A. de; LUMBRERAS, J.F.; COELHO, M.R.; ALMEIDA, J.A. de; CUNHA, T.J.F.; OLIVEIRA, J.B. de. Sistema brasileiro de classificação de solos. 3.ed. rev. e ampl. Brasília: Embrapa, 2013. 353p.

SILVA, M. de A.; ARANTES, M.T.; RHEIN, A.F. de L.; GAVA, G.J.C.; KOLLN, O.T. Potencial produtivo da cana-de-açúcar sob irrigação por gotejamento em função de variedades e ciclos. Revista Brasileira de Engenharia Agrícola e Ambiental, v.18, p.241-249, 2014. DOI: https://doi.org/10.1590/S141543662014000300001.

SILVA, R.F. da; BUENO, A.C.; RAMOS, P.J.R.B.; ORLANDI, R.D.M.; BORGES, M.T.M.R.; MEDEIROS, S.D.S. de; CECCATO-ANTONINI, S.R.; MARTIN, J.G.P.; SPOTO, M.H.F.; VERRUMA-BERNARDI, M.R. Avaliação da qualidade de açúcares mascavado. Revista de Ciências Agrárias, v.41, p.10981106, 2018. DOI: https://doi.org/10.19084/RCA18077.

VERA-GUTIÉRREZ， T.; GARCÍA-MUÑOZ， M.C.; OTÁLVARO-ALVAREZ, A.M.; MENDIETA-MENJURA, O. Effect of processing technology and sugarcane varieties on the quality properties of unrefined non-centrifugal sugar. Heliyon, v.5, e02667, 2019. DOI: https://doi.org/10.1016/j.heliyon.2019. e02667.

WANG, J.; ZHAO, T.; YANG, B.; ZHANG, S. Sucrose metabolism and regulation in sugarcane. Journal of Plant Physiology \& Pathology, v.5, p.1-6, 2017. DOI: https://doi.org/10.4172/2329955x.1000167.

WEERAWATANAKORN, M.; ASIKIN, Y.; TAKAHASHI, M.; TAMAKI, H.; WADA, K.; HO, C.-T.; CHUEKITTISAK, R. Physico-chemical properties, wax composition, aroma profiles, and antioxidant activity of granulated non-centrifugal sugars from sugarcane cultivars of Thailand. Journal of Food Science and Technology, v.53, p.4084-4092, 2016. DOI: https://doi.org/10.1007/s13197-016-2415-5.

WHITE JR., P.M.; VIATOR, R.P.; WEBBER III, C.L. Temporal and varietal variation in sugarcane post-harvest residue biomass yields and chemical composition. Industrial Crops \& Products, v.154, art.112616, 2020. DOI: https://doi.org/10.1016/j. indcrop.2020.112616. 